Therefor did the Swedish National Assyrian Organization (SNAO) take the initiative to start a knowledge-sharing project together with the Swedish Rheumatism Association and the Swedish Neuro-Association to inform and educate the kids and their parents with the Assyrian background.

Objectives: The aim of this project is to empower the persons and families suffering of an RMD or/and neurological disease among the immigrants from Syria and to break barriers within the immigran's society as well as saving on the national welfare system.

Results: To achieve such a project the SNAO applied for funds from the Swedish General Inheritance fund nad worked closely with the Swedish Rheumatism Association as well as the Swedish Neuro-Association.

The project included other stakeholders that could embrace the goal and use unconventional methods to mark the point and reach out to the target group.

- Organizing weekend seminars open for to the target group

- Working with Läsa för integration (Reading for integration) http://www. lasaforintegration.se/index.html

- Opratat is a theater group that lifts difficult subjects to the surface and make a pedagogic scen of the subject. http://anhoriga.se/opratat/

- The Swedish Disability Rights Federation: that enable the project to reach a broader target but also to reach the decision makers.

References: The project reach a great number of immigrant with an Assyrian background and could inform the attendees about their right and how the Swedish society works. This was of a great help to the families as well as the kids.

Disclosure of Interest: None declared

DOI: 10.1136/annrheumdis-2018-eular.7574

\section{PARE0012 THE FRENCH PATIENT'S ASSOCIATION AFLAR: HAS GENERATED THE FRENCH NATIONAL ALLIANCE AGAINST OSTEOPOROSIS AND THE FIRST GENERAL CONVENTION FOR OSTEOPOROSIS, THAT IS A CAMPAIGN TO CREATE A NATIONAL PROMOTING TOOL TO IMPROVE THE MANAGEMENT OF OSTEOPOROSIS.: 7 PRIORITIES TO BETTER TREAT PATIENTS I}

L. Grange ${ }^{1,2}$, B. Cortet ${ }^{3}$, T. Thomas ${ }^{4}$, F. Srour ${ }^{5}$, P. Guggenbuhl ${ }^{6}$, C. Roux ${ }^{7}$, P. Monod ${ }^{8}$, J. M. Feron ${ }^{9}$, F. Alliot- launois ${ }^{10}$, F. Tremollières ${ }^{11}$, G. Chalés ${ }^{2}$, J. Giraud ${ }^{12}$, E. Senbel ${ }^{13}$, G. Thibaud ${ }^{14}$, P. Niemczynski ${ }^{15}$, D.R. Bertholon ${ }^{16}$, C. F. Roques ${ }^{17}$, D. Buchon ${ }^{18}$, C. Bonnet ${ }^{19}$, H. Blain ${ }^{20}$, C. Rolland ${ }^{21}$, D. Lafarge ${ }^{22}$, L. Carton ${ }^{2}$, On behalf of French National Alliance Against Osteoporosis. ${ }^{1}$ Rheumatology, CHU Grenoble Alpes, Grenoble; ${ }^{2}$ AFLAR, Paris; ${ }^{3}$ Rheumatology, University Hospital, Lille; ${ }^{4}$ Rheumatology, University Hospital, Saint Etienne; ${ }^{5}$ CNOMK, Paris; ${ }^{6}$ Rheumatology, University Hospital, Rennes; ${ }^{7}$ Rheumatology, University Hospital Cochin, Paris; ${ }^{8}$ CFMR, castelnaudary; ${ }^{9}$ Orthopaedic Surgery and Traumatology Department, HUEP - Saint-Antoine; ${ }^{10}$ Pro-Rhumato, Paris;

${ }^{11}$ Menopause Unit and Metabolic bone diseases, Paule de Viguier Hospital, Toulouse; ${ }^{12}$ Coordinator, Empatient, Paris; ${ }^{13}$ SNMR, Marseille; ${ }^{14}$ ANDAR;

${ }^{15}$ ONPP; ${ }^{16}$ Director, Empatient, ${ }^{17}$ AFRETH, Paris; ${ }^{18}$ General Medicine university;

${ }^{19}$ Rheumatology, University Hospital, Limoges; ${ }^{20}$ Prevention and Treatment Center for Diseases of Ageing Antonin Balmes, University Hospital, Montpellier, ${ }^{21}$ Asthma \& Allergy; ${ }^{22}$ AFS, Paris, France

Background: Osteoporosis is a major public health issue with 5 million of French affected. Overall, she seriously underestimated, and costs are barely covered in France. Considering this situation, AFLAR were urged to create the so-called National Osteoporosis Alliance made up of 15 various stakeholders and patients. Methods: National consultations on osteoporosis rely methodologically on 2 pillars:First the bottom-up reporting on patient needs and expectations. Second the conduct of coordination meetings with various osteoporosis key stakeholders and patients as part of regional panel-discussions. The aim is to provide an overview of real obstacles contributing to the lack of government subsidies for osteoporosis and write consensual proposals compiled into a white paper.

Results: An online survey along with a citizen's panel were key to provide feedbacks on difficulties, knowledges and believes but also patient needs. From November 2016 to June 2017, 10 days of dialogue and debate covering 5 various topics were convened in 10 different cities: Consultation and consolidation work regarding proposals made during various panel-discussions allowed synthesis around one call: the creation of a real public health plan against osteoporosisrelated fractures relying on 7 key axis.

Conclusions: The human and medico-economic rational considering dramatic fallouts caused by osteoporosis has been illustrated many times over. The policy makers mobilization made by stakeholders through white paper release, a real manifesto for public health plan against osteoporosis-related fracture, remain a significant challenge to face.

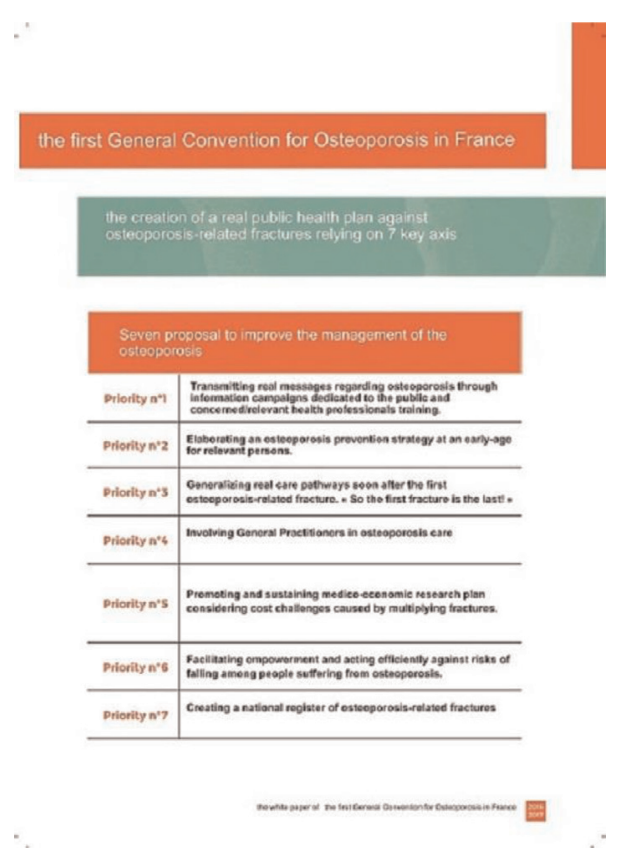

Disclosure of Interest: L. Grange Grant/research support from: ucb Lilly Amgen expanscience Roche company, B. Cortet : None declared, T. Thomas : None declared, F. Srour : None declared, P. Guggenbuhl : None declared, C. Roux None declared, P. Monod: None declared, J. M. Feron: None declared, F. Alliotlaunois: None declared, F. Tremollières : None declared, G. Chalés : None declared, J. Giraud : None declared, E. Senbel: None declared, G. Thibaud: None declared, P. Niemczynski: None declared, D. R. Bertholon : None declared, C. F. Roques : None declared, D. Buchon: None declared, C. Bonnet : None declared, H. Blain : None declared, C. Rolland : None declared, D. Lafarge : None declared, L. Carton: None declared

DOI: 10.1136/annrheumdis-2018-eular.3922

\section{PARE0013 SOURCES OF INFORMATION AND KNOWLEDGE ABOUT RHEUMATIC DISEASES AMONG PEOPLE WITH RHEUMATIC DISEASES IN POLAND AND IN OTHER EUROPEAN COUNTRIES}

J. Grygielska ${ }^{1}$, A. Kłak ${ }^{1}$, J. Owoc ${ }^{1}$, E. Gawińska-Drużba ${ }^{1}$, F. Raciborski². ${ }^{1}$ Department of Gerontology, Public Health and Didactics, National Institute of Geriatrics, Rheumatology and Rehabilitation; ${ }^{2}$ Medical University of Warsaw, Warsaw, Poland

Background: Knowledge on rheumatic and musculoskeletal diseases (RMDs) is an important factor in helping patients live independent lives as long as possible. The internet and easy access to all sorts of information make it seem that delivering appropriate information to patients is one of the key objectives of health promotion.

Objectives: The aim of this study was to evaluate patients' knowledge on RMDs and find out how and when they seek and retrieve relevant information. The results provide an opportunity to increase efforts in proper education of patients and health care professionals, reduce adverse effects of incorrect information and increase self-awareness as well as personal health responsibility among patients. Methods: We used questionnaires for patients with RMDs and carried out focus group interviews. The Computer-Assisted Web Interview Questionnaire was divided into 2 sections: one describing characteristics of respondents and evaluating importance of various information and its sources and the latter which tested knowledge on RMDs. The respondents were asked to rate their own knowledge and information provided by their physician. All the data were collected in 2017. We used two language versions of the questionnaire - Polish and English for international patients. The results from both groups were compared.

Both versions were distributed with the help of patient organizations. The link to the English version was distributed with the kind support from EULAR.

Results: We received 207 on-line responses - 140 in Polish and 67 in English Both language groups had similar characteristics, however the English-speaking 